\title{
Komunikasi Melalui Teknologi dan Media Sosial
}

Makalah Ini Disusun untuk Memenuhi Tugas pada Mata Kuliah Sistem Komunikasi

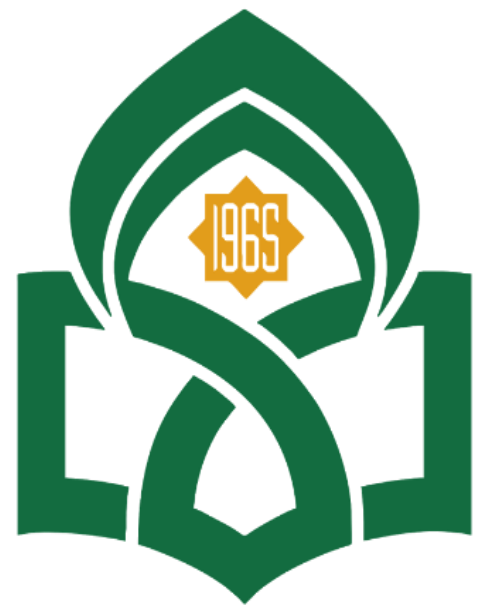

UNIVERSITAS ISLAM NEGERI

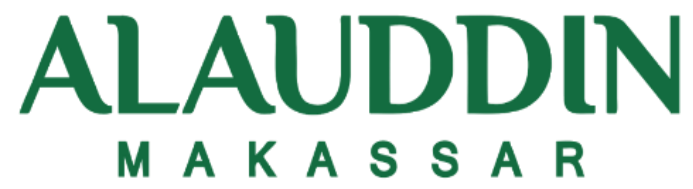

DISUSUN OLEH

NURHAYATI (90500120056)

NURUL ANNISA (90500120061)

FITRIANI PUTRI (90500120068)

PERBANKAN SYARIAH

FAKULTAS EKONOMI DAN BISNIS ISLAM UNIVERSITAS ISLAM NEGERI ALAUDDIN MAKASSAR TAHUN 2021 


\section{Kata Pengantar}

Segala puji bagi Allah SWT yang telah memberikan penulis kemudahan dalam menyelesaikan makalah tepat waktu. Tanpa rahmat dan pertolongan-Nya, penulis tidak akan mampu menyelesaikan makalah ini dengan baik. Tidak lupa shalawat serta salam tercurahkan kepada Nabi agung Muhammad SAW yang syafa'atnya kita nantikan kelak.

Penulis mengucapkan syukur kepada Allah SWT atas limpahan nikmat sehat-Nya, sehingga makalah yang berjudul "Mengelola Manajemen Sumber Daya Manusia (MSDM)" dapat diselesaikan. Makalah ini disusun guna memenuhi tugas mata kuliah Kewirausahaan. Penulis berharap makalah tentang pengelolaan manajemen sumber daya manusia ini dapat menjadi referensi bagi masyarakat dalam menerapkannya didalam kehidupan bermasyarakat.

Penulis menyadari makalah ini masih perlu banyak penyempurnaan karena kesalahan dan kekurangan. Penulis terbuka terhadap kritik dan saran pembaca agar makalah ini dapat lebih baik.

Apabila terdapat banyak kesalahan pada makalah ini, baik terkait penulisan maupun konten, penulis memohon maaf. Demikian yang dapat penulis sampaikan. Akhir kata, semoga makalah ini dapat bermanfaat. Wassalamu'alaikum warahmatullahi wabarakatuh. 


\section{Daftar isi}

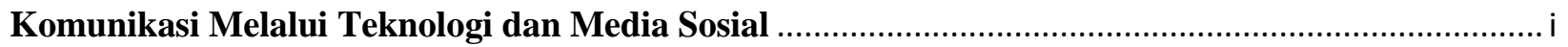

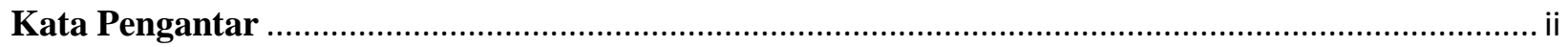

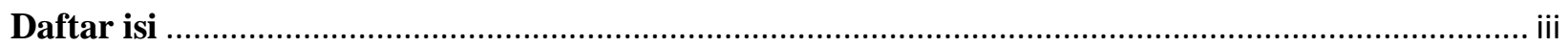

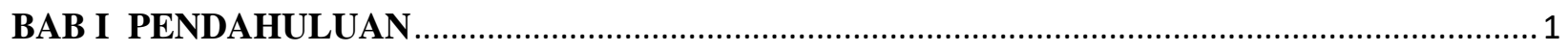

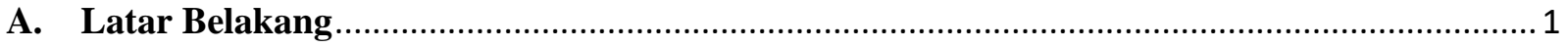

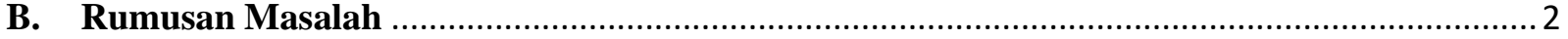

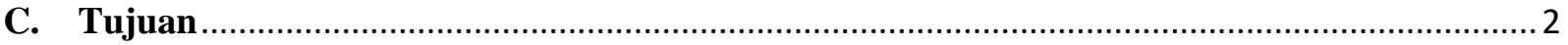

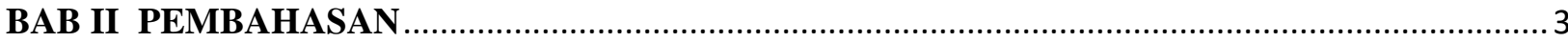

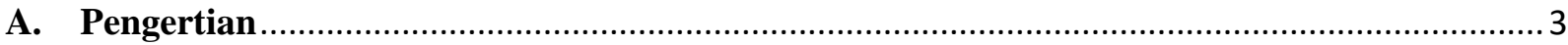

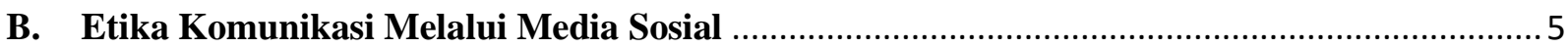

C. Peran Media Sosial Dalam Komunikasi Bisnis ............................................................... 7

D. Strategi Komunikasi Melalui Media Sosial ........................................................................ 14

E. Pengaruh Teknologi Komunikasi Dalam Masyarakat …................................................... 15

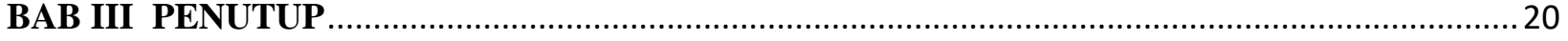

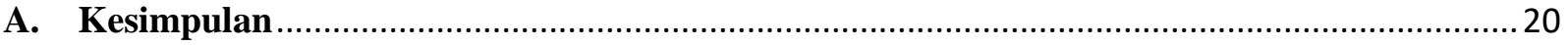

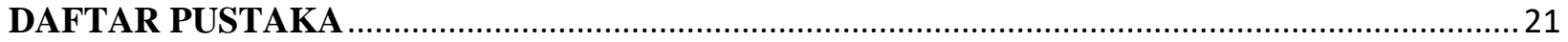




\section{BAB I \\ PENDAHULUAN}

\section{A. Latar Belakang}

Komunikasi merupakan hal yang sangat penting bagi manusia. Tanpa komunikasi maka manusia dapat dikatakan "tersesat" dalam menjalani hidup. Pentingnya komunikasi terlihat dari semakin inovatifnya perkembangan teknologi komunikasi itu sendiri. Akselerasi perkembangan teknologi komunikasi yang begitu cepat saat ini telah membawa manusia pada suatu tatanan baru. Sebuah tatanan dimana jarak dan waktu tidak lagi menjadi permasalahan untuk berkomunikasi. Pada awalnya manusia hanya menggunakan sandi berupa asap atau semaphore untuk berkomunikasi, kemudian berkembang menjadi telegraf, telepon analog, dan teleprinter setelah munculnya listrik. Kemudian dikembangkan alat komunikasi bernama telpon seluler (ponsel) yang efisien dan portabel (mobile) karena menggunakan jaringan tanpa kabel (nirkabel). Ponsel juga dibekali fitur pengiriman dan penerimaan pesan singkat (short-message-service, atau SMS).

Perkembangan teknologi dan informasi saat ini semakin pesat. Ini merupakan bentuk perubahan gaya hidup yang di hasilkan dari globalisasi yang terjadi dalam masyarakat. ${ }^{1}$ Munculnya internet sebagai integrasi teknologi komunikasi, menghasilkan media, gaya hidup baru, karir baru, mengubah peraturan dan pergeseran isu-isu sosial. Saat ini telah berkembang beragam situs media sosial di internet, seperti facebook, twitter, myspace, youtube, google plus dan sebagainya. Keunggulan dari situs atau aplikasi media sosial adalah desain multi platform, yaitu dapat diakses dan terhubung di berbagai perangkat digital seperti, komputer, laptop, tablet, handphone dan smartphone.

\footnotetext{
${ }^{1}$ Donni BU, Usir Galau Dengan Internet Sehat, (yogyakarta: Andi Offset, 2013) hlm. i
} 
Globalisasi dan modernisasi memacuh kemajuan masyarakat dalam hal teknologi. Salah satunya internet yang merupakan jaringan global antar komputer untuk

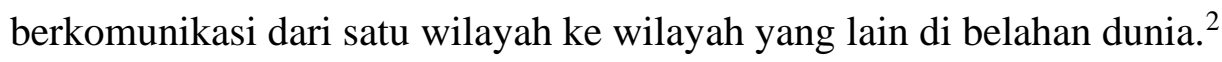

\section{B. Rumusan Masalah}

Berdasarkan uraian latar belakang di atas mengenai Manajemen Sumber Daya Manusia maka rumusan masalah yang dapat disajikan dalam pertanyaan adalah sebagai berikut:

1. Apa yang di maksud komunikasi melalui teknologi dan media sosial?

2. Apa saja etika yang perlu diperhatikan dalam komunikasi melalui media sosial?

3. Apa saja peran media sosial dalam komunikasi?

4. Apa saja strategi komunikasi melalui media sosial?

5. Bagaimana pengaruh teknologi komunikasi dalam masyarakat?

\section{Tujuan}

Berdasarkan uraian rumusan masalah diatas, maka tujuan dari pembuatan makalah ini adalah sebagai berikut:

1. Untuk mengetahui apa yang dimaksud komunikasi melalui teknologi dan media sosial?

2. Untuk mengetahui etika yang perlu diperhatikan dalam komunikasi melalui media sosial?

3. Untuk mengetahui peran media sosial dalam komunikasi?

4. Untuk mengetahui strategi komunikasi melalui media sosial?

5. Untuk mengetahui pengaruh teknologi komunikasi dalam masyarakat?

\footnotetext{
${ }^{2}$ Anjik Sukmaaji, Rianto, Jaringan Komputer konsep dasar pengembangan jaringan dan keamanan jaringan, (yogyakarta: Andi Offset, 2008) hlm. 22
} 


\section{BAB II \\ PEMBAHASAN}

\section{A. Pengertian}

Komunikasi merupakan aktifitas pertukaran pesan atau informasi dari setiap pengirim dan penerima pesan atau informasi dari setiap pengirim dan penerima pesan dari informasi tersebut. Komunikasi merupakan salah satu bagian yang paling dipengaruhi oleh adanya perkembangan teknologi (Perdana, 2013). Pengertian Komunikasi menurut pakar Josep A.Devito (2000) Komunikasi adalah proses penyampaian dan penerimaan pesan di antara dua orang atau kelompok kecil,dengan efek dan feed back langsung. Menurut Bernald Barelson dan Gery A. Steiner ,bahwa komunikasi adalah proses transmisi informasi,gagasan,emosi ,keterampilan dan sebagainya yang menggunakan simbol-simbol dalam proses transmisi penyampaian pesan. Jadi Komunikasi adalah suatu aktivitas penyampaian informasi, baik itu pesan, ide, dan gagasan, dari satu pihak ke pihak lainnya yang dilakukan secara langsung maupun tidak langsung (Sari, 2021).

Teknologi adalah bentuk kreasi dari manusia yang diwujudkan dengan alat, dan teknik tertentu sehingga dapat mempermudah suatu pekerjaan dalam menghasilkan sesuatu. Teknologi juga dapat didefinisikan sebagai pengunaan dan penerapan pengetahuan tentang alat-alat, teknik, metode atau sistem organisasi atau pun produk sebagai hasil akhir. Seiring dengan kemajuan zaman dan juga perkembangan peradaban manusia maka teknologi juga semakin berkembang dan canggih. Alhasil di era milenial kini mereka yang todak melek akan teknologi akan tertinggal oleh berbagai hal yang pastinya selalu mengalami perubahan setiap waktunya. Kata teknologi sendiri berasal dari kata Latin yang berakar dari kata texere, yang artinya menyusun atau 
membangun.Teknologi merupakan sebuah perangkat untuk membantu aktivitas kita dan dapat mengurangi ketidakpastian yang disebabkan oleh hubungan sebab dan akibat untuk mencapai suatu tujuan.Teknologi memiliki 2 aspek, yaitu hardwere (perangkat keras) dan software (perangkat lunak) (Sari, 2021).

Berdasarkan kesimpulan diatas maka pengertian teknologi komunikasi adalah sebuah sistem peralatan perangkat keras yang dibuat karena ada kendala dari segi ekonomi, sosial, politik yang digunakan untuk mengatasi, mempermudah dan meningkatkan indra pendengar dan melihat untuk digunakan untuk mengumpulkan, memproses, dan bertukar informasi (Sari, 2021). Teknologi komunikasi adalah suatu sistem yang dilakukan oleh masyarakat modern untuk saling berhubungan satu dengan yang lain untuk melakukan pertukaran pesan lewat panca indera sebagaimana fungsi komunikasi dalam manajemen logistik.

Sedangkan Media sosial adalah platform digital yang memfasilitasi penggunanya untuk saling bersosial, baik itu berkomunikasi atau membagikan konten berupa tulisan, foto dan video. Segala konten yang dibagikan tersebut akan terbuka untuk publik secara realtime. Media sosial adalah fenomena populer yang menarik banyak perhatian. Beberapa ahli pernah menyampaikan definisi mereka terhadap teknologi yang satu ini. Sejumlah pengertian media sosial menurut para ahli berikut.

a. B.K. Lewis (2010), media sosial adalah suatu label yang merujuk pada teknologi digital yang bisa memungkinkan orang-orang untuk saling melakukan interaksi, produksi dan bagi pesan.

b. Chris Brogan (2010), media sosial adalah satu perangkat alat komunikasi yang di dalamnya memungkinkan untuk terjadi jenis interaksi baru. 
c. Dave Kerpen (2011), media sosial adalah tempat kumpulan gambar, video, teks serta hubungan interaksi dalam jaringan antara baik individu atau kelompok seperti organisasi. (Pulix, 2021)

\section{B. Etika Komunikasi Melalui Media Sosial}

Komunikasi melibatkan interaksi antar anggota masyarakat. Dalam interaksi diperlukan norma-norma atau aturan-aturan yang berfungsi untuk pengendalian yang tujuannya adalah untuk tercapainya Ketertiban dalam masyarakat. Salah satu, upaya mewujudkan tertibnya masyarakat adalah adanya etika komunikasi yakni kajian tentang baik buruknya suatu tindakan komunikasi yang dilakukan manusia, suatu pengetahuan rasional yang mengajak manusia agar dapat berkomunikasi dengan baik. Komunikasi menandakan pula adanya interaksi antar -anggota masyarakat, karena komunikasi selalu melibatkan setidaknya dua orang. Dalam interaksi selalu diperlukan norma-norma atau aturan-aturan yang berfungsi untuk pengendalian atau social control. tujuannya untuk menciptakan masyarakat yang tertib. Salah satu bentuk untuk mewujudkan tertibnya masyarakat adalah adanya etika, yakni filsafat yang mengkaji baik-buruknya suatu tindakan yang dilakukan manusia.

Dengan demikian etika komunikasi adalah ilmu yang memperhatikan baik buruknya cara berkomunikasi. Etika komunikasi memperhatikan kejujuran dan terus terang, keharmonisan hubungan, pesan yang tepat, menghindai kecurangan, konsistensi antara pesan verbal maupun non-verbal serta memperhatikan apakah para komikator memotong suatu pembicaraan atau tidak. Etika komunikasi menjadi sangat penting ketika berkomunikasi dalam sebuah komunitas, komunitas menurut Wengner sebagaimana dibahas oleh Setiyani (2013) adalah sekelompok orang yang saling berbagi lingkungan, 
perhatian, masalah, serta memiliki keterkaitan atau kegemaran yang sama terhadap suatu topik (Mutiah, Albar, Fitriyanto, \& A.Rafiq, 2019, hal. 16-17).

Dalam kehidupan bersosial di masyarakat, istilah etika dikaitkan dengan moralitas seseorang. Orang yang tidak memiliki etika yang baik sering disebut tidak bermoral karena tindakan dan perkataan yang diambil tidak melalui pertimbangan baik dan buruk. karena menyangkut pertimbangan akan nilai-nilai baik yang harus dilakukan dan nilai-nilai buruk yang harus dihindari. Tidak adanya filter pertimbangan nilai baik dan buruk merupakan awal dari bencana pemanfaatan media sosial.

Etika berkomunikasi dalam implementasinya antara lain dapat diketahui dari komunikasi yang santun. Hal ini merupakan juga cerminan dari kesantunan kepribadian kita. Komunikasi diibaratkan seperti urat nadi penghubung Kehidupan, sebagai salah satu ekspresi dari karakter, sifat atau tabiat seseorang untuk saling berinteraksi, mengidentifikasikan diri serta bekerja sama. Kita hanya bisa saling mengerti dan memahami apa yang dipikirkan, dirasakan dan dikehendaki orang melalui komunikasi yang diekspresikan dengan menggunakan berbagai saluran, baik verbal maupun nonverbal. Pesan yang ingin disampaikan melalui komunikasi, bisa berdampak positif bisa juga sebaliknya. Komunikasi akan lebih bernilai positif, jika para peserta komunikasi mengetahui dan menguasai teknik berkomunikasi yang baik, dan beretika. Etika berkomunikasi, tidak hanya berkaitan dengan tutur kata yang baik, tetapi juga harus berangkat dari niat tulus yang diekspresikan dari ketenangan, kesabaran dan empati kita dalam berkomunikasi. Bentuk komunikasi yang demikian akan menghasilkan komunikasi dua arah yang bercirikan penghargaan, perhatian dan dukungan secara timbal balik dari pihak-pihak yang erkomunikasi. Komunikasi yang beretika, kini menjadi persoalan 
penting dalam penyampaian aspirasi. Dalam keseharian eksistensi penyampaian aspirasi masih sering dijumpai sejumlah hal yang mencemaskan dari perilaku komunikasi yang kurang santun. Etika komunikasi sering terpinggirkan, karena etika Berkomunikasi belum membudaya sebagai urat nadi kehidupan bermasyarakat dan bernegara. Adapun Etika komunikasi yang baik dalam media sosial adalah jangan menggunakan kata kasar, provokatif, porno ataupun SARA; jangan memposting artikel atau status yang bohong; jangan mencopy paste artikel atau gambar yang mempunyai hak cipta, serta memberikan komentar yang relevan (Mutiah, Albar, Fitriyanto, \& A.Rafiq, 2019).

\section{Peran Media Sosial Dalam Komunikasi Bisnis}

Komunikasi Bisnis adalah sebuah pertukaran informasi atau pesan yang dilakukan untuk menciptakan peluang dan keberhasilan dalam dunia usaha atau dunia bisnis. Dijaman yang semakin maju dan modern ini, kehidupan berbisnis semakin mudah untuk dilakukan. Ini terjadi karena peluang keberhasilan bisnis juga mulai meningkat seiring dengan berbagai kebijakan pemerinta, serta Penggunaan Teknologi Informasi dalam Komunikasi Bisnis. Penggunaan Teknologi Dalam Komunikasi Bisnis yang sering sekali digunakan adalah media sosial atau medsos.

Jika merujuk kepada Pengertian Media Sosial, maka penggunaan medsos pada komunikasi bisnis adalah komunikasi bisnis yang dilakukan menggunakan berbagai media sosial atau aplikasi sosial seperti Facebook, Instagram, Path, Twitter, dan aplikasi media sosial lainnya untuk menjalankan berbagai Fungsi Strategi Komunikasi Pemasaran. Namun untuk menggunakan media sosial dalam kegiatan bisnis hingga mendapatkan Pengaruh Teknologi dalam Komunikasi Bisnis yang signifikan ternyata tidaklah mudah. 
Adapun peranan dari penggunaan media sosial didalam komunikasi bisnis menurut (Sitepu, 2018). Diantaranya adalah :

\section{Membangun Jaringan}

Perkembangan Media Sosial di Indonesia berlangsung dengan sangat cepat, begitu juga pertumbuhan ekonomi dan bisnis juga meningkat setiap tahunnya. Ketika pebisnis sudah mulai memiliki bisnis yang berkembang, tentu sangat diperlukan jaringan yang luas untuk mengembangkan bisnisnya itu. Disinilah peran dan penggunaan media sosial dibutuhkan. Media sosial yang cepat dan mudah digunakan untuk berkomunikasi dengan siapa saja, tentunya akan semakin membuat komunikasi dapat dilaksanakan dengan lebih intens. Ketika komunikasi dijalankan dengan intens, tentunya jaringan yang dibangun akan memiliki kekuatan yang cukup untuk memperlebar area bisnis.

\section{Menerima Informasi dari Konsumen}

Pengaruh Budaya dalam Komunikasi Bisnis tentunya tidak bisa dilepaskan begitu saja, karena budaya juga memiliki suatu ikatan didalam diri konsumen untuk menentukan barang atau produk yang akan digunakannya. Misalnya saja di daerah Sumatera Utara yang memikili beragam budaya seperti budaya karo, budaya melayu dan sebagainya tentunya akan mempengaruhi perkembangan bisnis. Ketika pebisnis membuka bisnis fashion dibidang Melayu atau Karo, maka dapat dipastikan bisnis tersebut akan berjalan dengan lancar. Disinilah penggunaan media sosial dilibatkan untuk menerima informasi mengenai budaya, kesukaan, keinginan atau berbagai informasi lain dari konsumen. Contoh penggunaannya seperti membuat jejak pendapat pada suatu aplikasi medsos.

3. Memperkecil pengeluaran 
Dampak Negatif Dari Media Sosial pada bisnis hanya berupa rentannya transaksi uang disalah gunakan atau rentannya konsumen menjadi korban penipuan. Sedangkan dampak negatif komunikasi bisnis yang dilakukan secara konvensional seperti langsung mengunjungi kolega, langsung mengunjungi konsumen dan sebagainya tentunya membuat pengeluaran atau biaya pemasaran menjadi semakin besar. Ini berarti, ketika pebisnis mampu berbisnis dengan Etika Komunikasi di Media Sosial yang baik dan benar, maka penggunaan media sosial dalam komunikasi bisnis menjadi salah satu cara untuk memperkecil pengeluaran atau biaya pemasaran.

\section{Menjadi Tempat Iklan}

Penggunaan media sosial kini telah menjadi salah satu tempat iklan yang paling favorit. Selain karena biayanya murah, iklan di Medsos juga lebih mampu untuk menjangkau konsumen dari berbagai tempat dan usia. Hanya saja, iklan pada media sosial cenderung memiliki konten negatif ketimbang iklan yang dilakukan pada media TV atau media cetak yang pemasangannya lebih diawasi. Iklan yang kami maksud adalah iklan seharusnya tidak pantas untuk anak remaja seperti iklan game dewasa, iklan produk kecantikan bagi wanita dewasa hingga iklan alat kontrasepsi yang menggunakan model dewasa. Iklan ini tentunya memiliki Dampak Sosial Media terhadap Komunikasi Remaja Masa Kini.

\section{Cocok Untuk Pebisnis Pemula}

Komunikasi bisnis yang menggunakan media sosial sangat cocok untuk pebisnis dengan kategori pemula hingga menengah. Ketika pebisnis pemula belum memiliki modal yang besar untuk melakukan pemasaran, belum memiliki jaringan yang luas hingga belum memiliki konsep usaha yang baik, maka dengan menggunakan media sosial semuanya menjadi terselesaikan. Penggunaan medsos bagi pebisnis pemula bisa kita lihat, misalnya 
seorang pengguna facebook menawarkan berbagai produk barang bekas, produk elektronik, produk makanan atau kue hingga produk fashion melalui Timeline facebooknya, dan itu tidak dipungut biaya iklan.

\section{Menciptakan Brand Awareness}

Penggunaan medsos untuk menciptakan brand awareness sangatlah efektif untuk menyebarkan informasi dari merk tertentu. Ini biasanya dilakukan ketika produk masih baru dan dalam tahap promosi pada pebisnis yang ingin melihat tanggapan konsumen dan menginginkan agar konsumen cepat mengetahui produk tersebut. Contoh untuk menciptakan brand awareness melalui media sosial adalah dengan membuat berbagai postingan tentang sebuah produk secara berkesinambungan baik dengan menggunakan medsos spesialis, komunitas atau grup medsos hingga membuat website berbasis SEO atau search engine optimization.

\section{Terhubung Langsung Dengan Konsumen}

Komunikasi bisnis yang dijalankan dan dilakukan melalui media sosial, tentunya membuat pebisnis langsung terhubung dengan konsumen. Pada tahap ini, pebisnis dan konsumen kemungkinan besar akan memiliki alur komunikasi dari segala arah dan bukan hanya satu atau dua arah saja. Ketika pebisnis sudah terhubung dengan konsumen, maka dengan Strategi Marketing Online yang baik, pebisnis akan mampu mengubah opini, pandangan dan sikap konsumen.

\section{Riset Pasar}

Didalam komunikasi bisnis, riset pasar merupakan hal yang paling penting untuk mengetahui keinginan dan kemauan konsumen. Itulah sebabnya kenapa media sosial juga dapat digunakan sebagai alat untuk melakukan riset pasar pada berbagai tingkatan 
konsumen. Untuk melakukan riset pasar pada media sosial cukuplah mudah, hanya dengan melakukan polling survey atau jejak pendapat, maka riset pasar bisa didapatkan dengan mudah.

\section{Mendapatkan Konsumen}

Komuikasi Pemasaran Terpadu dalam dunia bisnis yang utama adalah untuk mendapatkan konsumen. Nah dengan menggunakan media sosial, konsumen dengan mudah untuk didapatkan. Hal ini terjadi karena promosi atau iklan yang dilakukan pada media sosial dapat disesuaikan dengan rentang usia, jenis kelamin, wilayah domisili, wilayah penjualan hingga menggunakan fenomena viral atau trending topic.

\section{Penentuan Target}

Aplikasi media sosial memiliki fitur targeting yang memunculkan berbagai informasi mengenai konsumen yang kita jadikan target pasar. Hal ini tentunya sangat berpengaruh bagi keberlangsungan bisnis. Contoh sederhanya ketika kamu memiliki bisnis fashion untuk anak remaja maka dengan menggunakan aplikasi medsos twiter dan membuat \#hastag misalnya \#Fashionremajakekinian, para remaja akan dengan mudah untuk melihat seluruh postingan kamu. Apalagi kalau \#hastag kamu menjadi viral atau tranding topic, dijamin konsumen kamu akan melimpah sesuai dengan target yang ditentukan.

\section{Lebih Efektif}

Tahap-tahap Komunikasi pada dunia medsos merupakan Proses Komunikasi Efektif dijaman ini. Siapa saja dan dimana saja dapat dengan mudah untuk saling bertukar informasi. Hal ini tentunya sangat baik jika diterapkan dan digunakan dalam dunia bisnis. Perlu diingat bahwa sekarang ini, masyarakat cenderung lebih suka berjelajah ria 
menggunakan smartphone, sehingga komunikasi menjadi lebih efektif ketika pebisnis juga menggunakan media sosial.

\section{Memperluas Pasar}

Sekarang ini, pengiriman sebuah barang dari Sabang sampai Merauke semakin mudah dan hanya membutuhkan waktu beberapa hari saja. Ketika pebisnis hanya memiliki toko di Aceh dan menggunakan media sosial dalam mengembangkan bisnisnya, maka tidak mungkin pebisnis tersebut akan mendapatkan pembeli berasal dari Jakarta atau Sulawesi atau bahkan dari Papua. Oleh sebab itu, penggunaan media sosial dalam komunikasi bisnis tidak bisa terlepas dari pengaruh jasa pengiriman atau ekspedisi. Atas dasar itu pula, area pasar dalam bisnis yang dilakukan akan semakin luas.

\section{Langsung Mendapatkan Respon Konsumen}

Ciri-ciri Media Sosial yang paling utama adalah berbasis pengguna. Karena berbasis pengguna, maka penggunaan bisnis dalam komunikasi bisnis akan mempermudah pebisnis untuk mendapatkan respon, umpan balik atau tanggapan dari konsumen. Respon atau feedback tersebut tentunya juga sangat penting untuk mengembangkan bisnis dan mendapatkan kepercayaan dari konsumen lainya, karena ketika konsumen A membeli barang dari pebisnis B dan memberikan respon atau feedback sangat memuaskan, maka konsumen $\mathrm{C}, \mathrm{D}$, dan $\mathrm{E}$ tidak akan ragu untuk membeli barang dari pebisnis $\mathrm{B}$.

14. Meningkatkan Pengunjung website

Dengan jaman yang semakin canggih terlebih lagi google menyediakan layanan AdSense yang juga dapat memberikan pemasukan pundi-pundi dollar bagi orang-orang yang memiliki website, penggunaan media sosial juga dapat digunakan untuk meningkatkan pengunjung website. Jadi ibaratkan satu kali dayung dua - tiga pulau 
terlampaui. Artinya, proses perkembangan bisnis juga semakin lancar, dan disisi lain pemasukan dari AdSense juga semakin meningkat.

\section{Penyebaran Informasi Lebih Cepat}

Pada tahun-tahun sebelumnya, proses penyebaran informasi tidaklah begitu cepat, hal ini tentunya juga mempengaruhi bisnis. Namun kini penyebaran informasi menjadi sangat cepat. Bayangkan saja dalam 1 jam, suatu kejadian dapat langsung viral atau menjadi trending topic.

\section{Melengkapi Kegiatan Pemasaran}

Peran Komunikasi Pemasaran dalam bisnis sangatlah besar, itulah sebabnya perusahaan rela mengeluarkan ratusan juta untuk melakukan pemasaran terhadap sebuah produk mereka. Jika biasanya pemasaran menggunakan media TV, Radio atau media cetak seperti baliho, spanduk, poster, selebaran hingga promosi di pusat perbelanjaan, maka pemasaran dirasa tidak lengkap tanpa penggunaan media sosial dalam komunikasi bisnis.

\section{Tidak Memiliki Batasan}

Jika komunikasi bisnis yang dilakukan seperti iklan atau promosi melakui TV memiliki batasan, lain halnya ketika menggunakan media sosial. Jika pada satu stasiun TV,dalam satu hari iklan hanya 20 kali, maka dengan menggunakan media sosial iklan tidak memiliki batasan penayangan dan penyebaran. Terdapat ribuan grup didalam satu jenis media sosial yang dapat terus menerus digunakan sebagai media promosi. Ini menunjukkan bahwa, selain murah dan mudah, media sosial juga dapat digunakan setiap saat tergantung kebutuhan. 


\section{Strategi Komunikasi Melalui Media Sosial}

Pemilihan strategi serta media yang tepat dapat berpengaruh terhadap berbagai aspek dalam perusahaan atau organisasi, salah satunya dalam hal membangun dan mempertahankan citra perusahaan atau organisasi di mata khalayak eksternal. Citra merupakan gambaran tentang objek di pikiran khalayak atau konsumen. Strategi pembentukan citra melalui media sosial saat ini banyak dimanfaatkan oleh organisasi atau perusahaan, baik melalui akun resmi ataupun menggunakan akun media sosial milik pribadi atau institusi lain. Bahkan saat ini, penggunaan media sosial sebagai strategi pembentukan citra juga telah digunakan oleh institusi-istitusi media massa di indonesia. Strategi komunikasi sendiri merupakan perpaduan dari perencanaan komunikasi dan manajemen untuk mencapai suatu tujuan. Menurut (Yoni \& Dkk, 2019) secara umum terdapat empat proses dalam pembentukan strategi, yaitu:

a. Mendefinisikan problem atau peluang.

Pada langkah ini, organisasi melalukan analisis situasi. Organisasi menyelidiki dan memantau pengetahuan, opini, sikap, dan perilaku pihak-pihak yang memiliki hubungan dan dipengaruhi oleh kebijakan serta tindakan organisasi. Riset memiliki peran yang sangat penting dalam langkah ini. dalam langkah ini, organisasi dapat menggunakan analisis SWOT (Strengths/kekuatan, Weakness/kelemahan, Opportunities/peluang, dan Threats/ancaman) untuk mengetahui keadaan organisasinya. Unsur Strengths dan Weakness merupakan unsur-unsur yang berasal dari dalam perusahaan. Sedangkan Opportunities dan Threats dikaji dari lingkungan luar perusahaan.

b. Perencanaan dan pemrograman. 
Informasi yang dikumpulkan melalui langkah pertama digunakan untuk membuat keputusan-keputusan yang terkait dengan organisasi dan publik. Organisasi juga merumuskan strategi untuk mencapai tujuan, tindakan dan komunikasi, taktik, serta sasaran dari program yang direncanakan. Perencanaan strategis melibatkan pembuatan keputusan tentang tujuan dan sasaran program, mengidentifikasi publik kunci, menentukan kebijakan atau aturan untuk memandu pemilihan dan penentuan strategi.

c. Mengambil tindakan dan berkomunikasi.

Langkah ketiga dalam proses ini adalah mengimplementasikan program aksi dan komunikasi yang telah direncanakan untuk mencapai tujuan program.

d. Mengevaluasi program.

Langkah terakhir dalam proses ini yaitu melakukan penilaian atas persiapan, implementasi, hasil dari program. Penyesuaian akan tetap dilaksanakan sembari program diimlementasikan dan didasarkan pada evaluasi atas feedback mengenai bagaimana program tersebut telah berjalan.

\section{E. Pengaruh Teknologi Komunikasi Dalam Masyarakat}

Perkembangan teknologi secara langsung akan berpengaruh terhadap perkembangan dalam dunia komunikasi. Perkembangan teknologi telah meningkatkan gaya hidup masyarakat. Manusia diciptakan untuk saling melengkapi, hal ini yang membuat manusia terdorong untuk dapat mempermudah cara berkomunikasi seperti. Alat komunikasi yang digunakan semakin canggih seiiring dengan berkembangan dunia modern. Kurang lebih 30 tahun yang lalu, di Indonesia baru mengenal adanya telepon genggam yang memiliki ukuran yang sangat besar dan berat, kemudian hingga saat ini, 
telepon genggam yang beredar semakin hari semakin tipis dan ringan. Menurut (Perdana, 2013) terdapat 12 Pengaruh Teknologi Komunikasi Dalam Masyarakat.

\section{Memudahkan Komunikasi}

Suka tidak suka kehadiran teknologi sangat memudahkan dalam komunikasi. Kini setiap orang dengan bantuan teknologi dapat berkomunikasi dalam waktu yang cepat dan juga tanpa ada batasan jarak. Tentu saja hal ini memberikan pengaruh positif pada perkembangan dunia komunikasi. Terlebih lagi jika dibandingkan dengan jaman 10-20 tahun yang lalu, maka akan terlihat bagaimana teknologi memberikan sentuhan terbaiknya dalam bidang komunikasi seperti penerapan komunikasi dalam jaringan.

\section{Mempercepat Komunikasi}

Jika dahulu dengan berkirim surat anda akan bisa mendapatkan balasannya paling cepat 2 minggu. Kini ceritanya akan jauh berbeda, sebab dalam hitungan detik anda sudah bisa mendapatkan balasan pesan jika berkirim pesan lewat sms. Tentu saja hal ini tidak akan terjadi tanpa adanya pengaruh teknologi yang diaplikasikan dalam bidang komunikasi. Sebab kini anda bisa dengan mudah dan cepat mendapatkan segala informasi, sehingga ketika ada hal yang urgent dapat segera mengetahui dan mengatasinya dalam peranan komunikasi dalam media sosial.

\section{Memudahkan Pekerjaan}

Tidak dipungkiri jika kemudian komunikasi hadir dalam mempermudah pekerjaan. Penggunaan komputer dan internet saat ini semakin memudahkan dan mengefisiensikan pekerjaan manusia. Jika dahulu anda harus menulis laporan, mengetik menggunakan mesin tik, namun dengan hadirnya teknologi kini segala pekerjaan anda lebih mudah. Dengan 
program yang tersedia anda tinggal memasukkan data dan membiarkan komputer mengolahnya.

\section{Komunikasi Lebih Efisien}

Jika dahulu komunikasi berjalan dengan sangat lambat dan hanya bisa dilakukam face to face. Kini berkat teknologi semuanya jadi lebih mudah, anda bahkan bisa melihat satu sama lain tanpa harus berdekatan. Jarak bukan lagi menjadi penghalang selama anda menggunakan gawai yang canggih. Bahkan kini hampir semua alat komunikasi dipadukan dengan teknologi ini. So, saat ini jika bicara soal komunikasi maka rasanya sudah tidak ada batasan dan kekurangannya lagi, sebab perkembangan teknologi akan langsung berimbas pada teknologi komunikasi dalam media komunikasi modern .

\section{Peralatan Komunikasi Lebih Canggih}

Hadirnya gawai dan peralatan komunikasi yang canggih tentunya dipengaruhi oleh perkembangan kecanggihan teknologi. Saat ini ponsel yang dibandrol dengan harga 1 jutaan saja bahkan sudah bisa mengaplikasikan teknologi yang canggih. Karena itulah kemudian kini banyak sekali beredar ponsel dengan harga ekonomi namun dibalut dengan teknologi yang menjanjikan. Tentu saja hal ini sangat membantu dan juga memberikan pengaruh bagi perkembangan dalam dunia perkomunikasian.

\section{Akses Informasi Lebih Cepat}

Dengan adanya perkembangan teknologi terutama penggunaan internet dalam komunikasi. Kini anda bisa dengan mudah mendapatkan informasi dengan cepat. Terlebih lagi saat ini banyak sekali provider komunikasi yang sudah meningkatkan kecepatan aksesnya. Tentu saja hal ini semakin mempengaruhi proses informasi dalam komunikasi dapat diperoleh dengan lebih cepat, dahulu berkembag teknologi $3 \mathrm{G}$ kini anda bisa mengakses segala 
informasi dengan lebih cepat dengan bantuan jaringan 4G yang pastinya akan membuat anda semakin puas dan menyenangkan dalam berkomunikasi.

\section{Menghubungkan Banyak Orang}

Ada banyak sekali kisah orang orang yang terputus kontak atau bahkan hilang kembali dapat bertemu lewat jaringan komunikasi. Tentu saja hal ini merupakan sebuah keajaiban yang hanya bisa diberikan oleh sentuhan teknologi dalam komunikasi. Kehadiran teknologi dalam komunikasi memungkinkan banyak orang untuk dapat saling terhubung melalui media sosial, bahkan kita dapat mengenal banyak orang dari berbagai belahan dunia. Tentu saja hal ini serupa dengan dunia berada dalam gengaman anda sebagai pengaruh media baru dalam komunikasi .

\section{Akses Tak Terbatas}

Kini dimanapun anda berada dibelahan bumi manapaun tetap dapat berkomunikasi dengan keluarga tanpa ada hambatan. Tentunya hal ini semakin mengikis jarak yang jauh jadi dekat dan yang dekat bisa menjadi jauh. Pastinya teknologi memberikan pengaruh terhadap kemudahan dalam akses yang tak terbatas bukan hanya mengenai informasi. Namun juga menghapus jarak yang jauh sehingga kini dimanapun anda berada selama masih terjangkau sinyal provider maka jangan takut akan kehilangan informasi.

\section{Persaingan Di Bidang Teknologi Komunikasi}

Tahukan anda bahwa perkambangan teknologi dalam komunikasi juga memunculkan persaingan. Saat ini semua provider dan juga produsen gawai berlomba lomba menciptakan teknologi komunikasi yang dapat digunakan oleh manusia. Perkembangan teknologi menciptakan persaingan yang semakin ketat dan juga persaingan sengit. Ada yang 
membandrol dengan harga murah dengan teknologi standar dan juga harga sekangut dengan kecanggihan teknologi yang mumpuni.

10. Kemudahan Bertukar Informasi

Perkembangan teknologi komunikasi menyebabkan banyak sekali kemudahan dapat dirasakan oleh manusia. Salah satunya adalah kemudahan untuk saling bertukar informasi. Anda dapat dengan mudah mendapatkan informasi dari berbagai sumber dan dari belahan dunia manapun. Anda juga bisa memantau setiap informasi terbaik di semua bidang baik politik, sosial, hingga ekonomi.

\section{Mendekatkan Jarak}

Perkembangan teknologi dalam komunikasi mampu mengikis jarak antar belahan dunia. Anda bahkan bisa tersa sangat dekat dengan saudara atau kerabat yang letaknya bisa jadi berada pada zona waktu yang berbeda. Sehingga tentunyanya tidak akan ada hanbatan yang bisa dirasakan. Hanya saja memang masih erbatas pada tidak adanya kemampuan untuk bersentuhan secara fisik, sebab hingga kini masih belum ditemukan teknologi yang demikian.

\section{Kecepatan perkembangan Dunia}

Tentu saja dengan adanya teknologi komunikasi yang semakin berkembang menyebabkan kecepatan dalam perkembangan dunia. Teknologi komunikasi yang berkemabang menyebabkan perkembangan di berbagai bidang baik itu sosial, politik bahkan hingga ekonomi. 


\section{BAB III \\ PENUTUP}

\section{A. Kesimpulan}

Teknologi komunikasi adalah sebuah sistem peralatan perangkat keras yang dibuat karena ada kendala dari segi ekonomi, sosial, politik yang digunakan untuk mengatasi, mempermudah dan meningkatkan indra pendengar dan melihat untuk digunakan untuk mengumpulkan, memproses, dan bertukar informasi.

Etika berkomunikasi dalam implementasinya antara lain dapat diketahui dari komunikasi yang santun. Hal ini merupakan juga cerminan dari kesantunan kepribadian kita. Komunikasi diibaratkan seperti urat nadi penghubung Kehidupan, sebagai salah satu ekspresi dari karakter, sifat atau tabiat seseorang untuk saling berinteraksi, mengidentifikasikan diri serta bekerja sama. Kita hanya bisa saling mengerti dan memahami apa yang dipikirkan, dirasakan dan dikehendaki orang melalui komunikasi yang diekspresikan dengan menggunakan berbagai saluran, baik verbal maupun nonverbal. Pesan yang ingin disampaikan melalui komunikasi, bisa berdampak positif bisa juga sebaliknya.

Adapun peranan dari penggunaan media sosial didalam komunikasi bisnis menurut (Sitepu, 2018). Diantaranya adalah: Membangun Jaringan, Menerima Informasi dari Konsumen, Memperkecil pengeluaran, Cocok Untuk Pebisnis Pemula, Menciptakan Brand Awareness, Terhubung Langsung Dengan Konsumen, Riset Pasar, Mendapatkan Konsumen, Penentuan Target, Lebih Efektif, Memperluas Pasar, Langsung Mendapatkan Respon Konsumen, Meningkatkan Pengunjung website, Penyebaran Informasi Lebih Cepat, Melengkapi Kegiatan Pemasaran, dan Tidak Memiliki Batasan. 


\section{DAFTAR PUSTAKA}

Mutiah, T., Albar, I., Fitriyanto, \& A.Rafiq. (2019). Etika Komunikasi Dalam Menggunakan Media Sosial. Global Komunika, 1(1), 20-21.

Perdana, R. (2013, Juni 24). Pengaruh Teknologi Komunikasi Dalam Masyarakat. Dipetik 12 05, 2021, dari Diskominfosantik: http://diskominfosantik.bekasikab.go.id/berita/601/pengaruh-teknologi-komunikasidalam-masyarakat\#

Pulix. (2021, September 18). Media Sosial Adalah: Contoh hingga Manfaatnya bagi Pebisnis. Dipetik Desember 05, 2021, dari Populix: https://www.info.populix.co/post/media-sosialadalah

Sari, A. M. (2021, June 28). Apa Yang Dimaksud Dengan Teknologi Komunikasi ? Dipetik Desember 05, 2021, dari FIK-TI NEWS: https://fikti.umsu.ac.id/apa-yang-dimaksuddengan-teknologi-komunikasi/

Sitepu, J. (2018, Januari 18). 17 Penggunaan Media Sosial Dalam Komunikasi Bisnis. Dipetik Desember 2021, 06, dari Pakarkomunikasi.com: https://www.google.com/amp/s/pakarkomunikasi.com/penggunaan-media-sosial-dalamkomunikasi-bisnis/amp

Yoni, N. P., \& Dkk. (2019). Strategi Komunikasi Melalui Media Sosial Dalam. Fakultas Ilmu Sosial Dan Ilmu PolitikUniversitas Udayana. 